\title{
EFFECT OF NUTRITION ON THE RESISTANCE OF PIGS TO ORAL INFECTION WITH MYCOBACTERIUM INTRACELLULARE
}

\author{
M. PAVLAS, M. DVOŘ́K and I. HERZIG \\ Veterinary Research Institute, 62132 Brno
}

Received fanuary 19, 1984

\begin{abstract}
Pavlas, M., M. Dvořák, I. Herzig: Effect of Nutrition on the Resistance of Pigs to Oral Infection with Mycobacterium intracellulare. Acta vet. Brno, 53, 1984: 169 to 174 .

Twenty-seven Large White $\times$ Landrace pigs were infected orally with a culture of Mycobacterium intracellulare serotype 4,8 at the rate of $1 \mathrm{mg}$ per $\mathrm{kg}$ body mass at 7 weeks of age to study the effect of nutrition on the resistance of pigs to mycobacteriosis.

The differing quality of feed mixtures fed ad libitum did not affect the formation of the specific granular inflammation in the mesenteric, submandibular and postpharyngeal lymph nodes after a single massive infection with $M$. intracellulare. Excretion of $M$. intracellulare in the faeces was found 3 to 8 weeks after infections.

The response to avian PPD tuberculin was delayed in pigs fed feed mixture SOL of a biologically lower quality. The beneficial effect of A1, a feed mixture of a higher quality, was manifested by more rapid devitalization of $M$. intracellulare in gross caseous lesions, which promoted the debacillization of the experimentally infected pigs.
\end{abstract}

\section{Mycobacteriosis, nutrition resistance.}

The development of large herds requires effective measures preventing the development of mass diseases. An important part of prevention is adequate and wholesome nutrition of animals ensuring their resistance to infectious diseases which account for a considerable proportion of animal losses in both large-capacity units and conventional herds.

One of infectious diseases that affect adversely the health state of pigs is tuberculosis which in 1980 was found in Czechoslovakia in $42116(0.75 \%)$ of slaughter pigs. The relation of nutrition to the incidence and clinical forms of tuberculosis in man and animals has been documented in the pertinent literature by a large number of statistical data, some of which were verified by exact experiments (Downes 1950; Hole 1955; Kábrt 1962; Gontzea 1974; a. o.). It has become clear that nutrition, an important part of the outer environment, affects the physiological processes of the human and animal organism and plays a major role, together with other factors, in the resistance and health state of the body. It was particularly before effective antituberculous drugs had been introduced that nutrition was an important part of the prevention and treatment of tuberculosis. There is evidence to indicate that insufficient and deficient nutrition aggravates the course of the disease and reduces the resistance to tuberculosis. On the other hand, it has also been found that excessive nutrition fails to have a beneficial effect on the resistance to tuberculosis, particularly in cases where carbohydrates dominate over proteins. Therefore fattening diets may also affect adversely the resistance to tuberculosis. Schaedker and Dubos (1959) described the effect of the dietary amino acid pattern on the susceptibility of mice to bacterial infections including tuberculosis.

The majority of investigators have concluded that a feed of low nutritional value and an insufficient amount of feed affect adversely the resistance of animals to tuberculosis. The effect of 
nutrition on the resistance of pigs to avian tuberculosis and atypical mycobacteria of reduced virulence has not yet been investigated.

The object of our study was to elucidate the role of nutrition and feed mixtures with differing crude protein $(\mathrm{N} \times 6.25)$ content and growth promoter supplements on the resistance of pigs to infection with Mycobacterium intracellulare which has recently been involved to a considerable degree in the incidence of gross caseous lesions in mesenteric, submandibular and postpharyngeal lymph nodes.

\section{Materials and Methods}

Twenty-seven Large White $\times$ Landrace piglets weaned at 4 weeks of age were employed. They were divided into two groups. Group A, comprising 14 piglets, was fed a commercial prestarter (ČOS 1) for 2 weeks after weaning, a commercial starter (ČOS 2) from 15 to 35 days after weaning and then a feed mixture for growing pigs (A 1). Group 3, comprising 13 piglets, received COS 1 mixed with and equal part maize meal containing 6 per cent lard for 2 weeks after weaning and ČOS 2 mixed with an equal part of maize meal containing 6 per cent lard from 15 to 35 days after weaning and then a feed mixture for growing pigs of a lower quality (SOL). All the feed mixtures were offered in the dry state ad libitum in self-feeders. Water was available from automatic waterers.

The pigs were infected with a semiwet culture of $M$. intracellulare serotype 4,8 at the rate of $1 \mathrm{mg}$ per $\mathrm{kg}$ body mass at 7 weeks of age. The mycobacterial suspension in the concentration of $5 \mathrm{mg}$ culture per $\mathrm{ml}$ saline was administered to animals on the root of the tongue as a single dose using a syringe with a rubber probe. The mean body mass at weaning in groups A and B was 9.46 and $9.11 \mathrm{~kg}$ respectively. Before being infected, the animals were examined with avian PPD tuberculin with negative results. After they were infected, disinfection of the pens was carried out daily with a 5 per cent solution of Odorit.

The gains in body mass, feed consumption, dynamics of the response to avian PPD and excretion of mycobacteria in the faeces were followed throughout the experiment. The pigs were slaughtered 99 to 106 days after infection. The degree of the resistance to mycobacteria was evaluated according to the degree of reactivity to avian PPD, excretion of mycobacteria in the faeces, patho-anatomical changes and bacteriological examination.

For demonstration of mycobacteria in the faeces, rectal swabs were taken at one-day to weekly intervals. The faeces were prepared for culture by the method of Beerweth (1971) for examination of samples of the outer environment. Patho-anatomical examination covered changes in the lymph nodes, parenchymatous organs and in the intestinal mucosa and wall. Non-specific gross changes in the lymph nodes or organs without characteristic caseation or in the presence of hepatic foci corresponding to hepatitis interstitialis nodosa were evaluated as dubious. Samples for cultivation were taken from both grossly altered and unaltered lymph nodes and organs. The tissues were ground in a mortar and after treatment with $1 \mathrm{M} \mathrm{HCl}$ and neutralization with $\mathrm{NaOH}$ were inoculated into Petragnani's medium, Stonebrink's medium and into Sula's liquid medium. The inoculated culture media were incubated two months at $37^{\circ} \mathrm{C}$. The isolated cultures were examined by biochemical tests and serotyping to confirm their identity with the infecting mycobacterial culture.

\section{Results}

During the first 35 post-weaning days the gain in body mass per animal per day was $0.459 \mathrm{~kg}$ in Group A piglets fed feed mixtures COS 1 and ČOS 2 and only $0.306 \mathrm{~kg}$ in Group B piglets receiving these two feed mixtures with maize meal and fat, with feed consumption per kg gain being 29.6 per cent higher in Group B than in Group A. In the following period under study the gain in body mass per animal per day was $0.642 \mathrm{~kg}$ in Group A and $0.451 \mathrm{~kg}$ in Group $\mathrm{B}$, with feed consumption being 54 per cent higher in the latter.

The responses to avian PPD are shown in Fig. 1. The response to $100 \mathrm{TU}$ of avian PPD was shown by 60 per cent of the pigs of both groups 41 days after infection. The response to $50 \mathrm{TU}$ of avian PPD 50 days after infection was less in Group B than in Group A. Ninety days after infection no difference was 
Active excretion of the infecting mycobacteria in the faeces was first demonstrated 3 weeks after infection in Group B and 4 weeks after infection in Group A. Both groups of pigs excreted $M$. intracellulare up to 8 weeks, the peak of excretion being recorded 35 days after infection. During the next part of the observation period, i. e. 9 to 14 weeks after infection, the faeces were negative for $M$. intracellulare in both groups of animals.

Patho-anatomical and bacteriological examination of pigs slaughtered 99 to 116 days after infection showed that the differing composition of the feed mixtures fed ad libitum had no effect on the production of caseous lesions in the mesenteric, submandibular and postpharyngeal lymph nodes. Specific lesions of the size of rice grains to bean seeds suggestive of the alternative form of mycobacteriosis were found in the mesenteric lymph nodes of 12 pigs (85.7\%) of Group A and 11 animals $(84.7 \%$ ) of Group B. The findings in the submandibular and postpharyngeal lymph nodes recorded in 5 animals of each group also indicated the same susceptibility to $M$. intracellulare in the two groups.

Bacteriological examination of the lymph nodes, however, showed that mycobacteria in the gross lesions were devitalized more rapidly in Group A. Culture of the mesenteric lymph nodes yielded positive results in 28.5 per cent of pigs in Group A and in 69.2 per cent of pigs in Group B (Table 1). The difference was significant $(P<0.98)$. Similar results were found on culture of the submandibular and postpharyngeal lymph nodes where positive findings in Group B exceeded more than twice those recorded in Group A. Culture of the parenchymatous grgans and Peyer's patches yielded negative results in all the animals. On bacteriolooical examination, $M$. intracellulare was also isolated from one third to one half

Table 1

Laboratory examination of the lymph nodes and organs of pigs infected orally with Mycobacterium intracellulare

\begin{tabular}{|c|c|c|c|c|c|c|c|c|c|c|}
\hline \multirow{4}{*}{ Group } & \multirow{4}{*}{$\begin{array}{l}\text { No. } \\
\text { pigs }\end{array}$} & \multicolumn{9}{|c|}{ Organ } \\
\hline & & \multicolumn{5}{|c|}{ lymph nodes } & \multirow{2}{*}{\multicolumn{2}{|c|}{$\begin{array}{l}\text { Parenchyma- } \\
\text { tous organs }\end{array}$}} & \multirow{2}{*}{\multicolumn{2}{|c|}{$\begin{array}{l}\text { Peyer's } \\
\text { patches }\end{array}$}} \\
\hline & & \multicolumn{3}{|c|}{ mesenteric } & \multicolumn{2}{|c|}{$\begin{array}{l}\text { postpharyngeal } \\
\text { submandibular }\end{array}$} & & & & \\
\hline & & $\begin{array}{l}\text { pathoanatomi- } \\
\text { cal finding }\end{array}$ & $\begin{array}{l}\text { No. } \\
\text { pigs }\end{array}$ & $\begin{array}{l}\text { culture } \\
\text { positive }\end{array}$ & $\begin{array}{l}\text { No. } \\
\text { pigs }\end{array}$ & $\begin{array}{l}\text { culture } \\
\text { positive }\end{array}$ & $\begin{array}{l}\text { No. } \\
\text { pigs }\end{array}$ & $\begin{array}{l}\text { culture } \\
\text { positive }\end{array}$ & $\begin{array}{l}\text { No. } \\
\text { pigs }\end{array}$ & $\begin{array}{l}\text { culture } \\
\text { positive }\end{array}$ \\
\hline \multirow{3}{*}{ A } & \multirow{3}{*}{$100 \%$} & Positive & $\begin{array}{l}12 \\
85.7 \%\end{array}$ & $28.5 \%$ & $\begin{array}{r}5 \\
35.7 \%\end{array}$ & $\begin{array}{l}2 \\
14.2\end{array}$ & 0 & 0 & 0 & 0 \\
\hline & & Dubious & $7.1 \%$ & 0 & $7.1 \%$ & 0 & $7.1 \%$ & 0 & 0 & 0 \\
\hline & & Negative & $7.1 \%$ & 0 & $\begin{array}{l}8 \\
57.2 \%\end{array}$ & $21.3 \%$ & $\begin{array}{r}13 \\
92.9 \%\end{array}$ & 0 & $14 \%$ & 0 \\
\hline \multirow{3}{*}{ B } & \multirow{3}{*}{$100 \%$} & Positive & $\begin{array}{c}11 \\
84.7 \%\end{array}$ & $69.2 \%$ & $\begin{array}{r}5 \\
38.5 \%\end{array}$ & $\begin{array}{r}4 \\
30.7 \%\end{array}$ & 0 . & 0 & 0 & 0 \\
\hline & & Dubious & $\begin{array}{l}2 \\
15.3 \%\end{array}$ & 0 & $7.7 \%$ & 0 & 0 & 0 & 0 & 0 \\
\hline & & Negative & 0 & 0 & $\begin{array}{c}7 \\
53.8 \%\end{array}$ & $\begin{array}{r}4 \\
30.7 \%\end{array}$ & $13 \%$ & 0 & $13 \%$ & 0 \\
\hline
\end{tabular}


of pigs with negative gross findings in the submandibular and postpharyngeal lymph nodes, with positive cultural finding being more frequent in Group B fed feed mixture SOL of lower quality than in Group A.

\section{Discussion}

The results reported in this study show that pigs are susceptible to $M$. intracellulare even when infected with a single oral dose and fed a nutritionally adequate diet. The fact that 25 of 27 pigs became infected after a single oral dose is due, among other things, to the massiveness of the dose.

From the dynamics of the response to avian PPD it appears that intradermal tuberculin testing is a reliable diagnostic method in cases where pigs are examined about three months after infection. However, active excretion of $M$. intracellulare in the faeces was not demonstrated at this time.

The results reported here confirm the views of some writers mentioned in Introduction that nutrition is one of the factors promoting the resistance of animals to tuberculos:s. The present findings extend the observation to date in that biologically sound nutrition has a beneficial effect by devitalizing mycobacteria and debacillizing pigs infected with $M$. intracellulare.

\section{Vliv výživy na odolnost prasat $k$ perorální infekci Mycobacterium intracellulare}

$\mathrm{Na} 27$ prasatech, křížencích $\mathrm{BU} \times \mathrm{L}$, experimentálně infikovaných per os ve stáří 7 týdnů, kulturou $M$. intracellulare, serotyp 4,8 v dávce $1 \mathrm{mg}$ na kg živé hmotnosti, byl sledován vliv výživy na odolnost prasat proti mykobakterióze.

$\mathrm{V}$ pokusech bylo zjištěno, že rozdílná kvalita krmných směsí podávaná ad libitum neovlivnila při jednorázové masivní infekci prasat $M$. intracellulare tvorbu specifického granulačního zánětu $\mathrm{v}$ mízních uzlinách mezenteriálních, podčelistních a zahltanových. Vylučování $M$. intracellulare trusem bylo zjištěno v období 3-8 týdnů po infekci.

Při sledování dynamiky alergie na PPD aviární byla zjišsěna opožděná reaktibilita na tuberkulin u skupiny prasat krmených směsí SOL. Př́znivý vliv biologicky hodnotnější směsi $\mathrm{Al}$ se projevil v rychlejší devitalizaci $M$. intracellulare $\mathrm{v}$ makroskopicky zesýrovatělých změnách, což př́iznivě ovlivnilo debacilizaci experimentálně infikovaných prasat.

Влияние питания на устойчивость поросят к пероральной инфекции Mycobacterium intracellulare

На 27 поросягах, помеси белая породистая х Ландрас, экспериментально инфицированных перорально в возрасте 7 суток культурой $M_{i}^{\prime}$. intracellulare, серологический тип 4, 8 дозой 1 мг на 1 кг живой массы, проводились исследования влияния питания на устойчивость поросят к микобактериозу.

В ходе экспериментов было установлено, что подаваемое вволю разное качество кромовых смесей не оказало при однократной массивной инфекции 
поросят M. intracellulare влияния на образование специфического грануляционного воспаления в мезенгериальных, подчелюстных и заглоточных лимфатических узлах. Выделение $M$. intracellulare калом было установлено в период 3-8 недель после инфекции.

При исследовании динамики аллергии на PPD птичий была установлена запоздалая реактивная способность у туберкулина на группе поросят, откармливаемых смесью SOL, Благоприятное влияние биологически более питательной смеси A1 проявилось в более быстрой девитализации $M$. intracellulare в макроскопически сыровидных образованиях, что оказало положительное влияние на ликвидацию бацилл экспериментально инфицированных поросят.

\section{References}

BEERWERTH, W.: Die mykobakteriele Bodenflora im Ablauf der Jahreszeiten. Praxis der Pneumologie vereinigt mit der Tuberkulosearzt, 11, 1971: 661-668.

DOWNES, J.: An experiment in the control of tuberculosis among Negroes. Milbank mem. Found. Quart., 18, 1950: 127-159.

GONTZEA, I.: Nutrition and anti-infectious defence. 1. ed. Basel 1974: 287.

HOLE, N. H.: Observations on the pathogenesis, infection spread and diagnosis. Control of Johne's disease. European Productivity Agency, Paris. Project. 217, 1955: 83-90.

KÁBRT, J.: Význam výživy při tuberkulóze. In: Dražan, J.: Tuberkulóza hospodášských zviřat. Praha, CAZV, SZN 1962: 68-72.

SCHAEDKER, R. W. - DUBOS, R. J.: Effect of dietary proteins and amino acids on the susceptibility of mice to bacterial infections. J. exp. Med., 110, 1959: 929-934. 